\title{
EFFECT OF PHYTOHORMONES PRODUCED BY PGPR (RHIZOBIUM) STRAINS ON IN-VITRO PROPAGATION OF DATE PALM (Phoenix dactylifera L.) ZAGHLOUL CULTIVAR
}

\author{
EL-SHARABASY, SH. F. ${ }^{1}$, D. M. SWELIM ${ }^{2}$ AND A. A. RAGAB ${ }^{2}$ \\ 1. The Central Laboratory of date palm Research and Development, ARC, Giza \\ 2. Microbiology Dep., Soil, water and Environment Res. Ins., ARC, Giza
}

(Manuscript received 18 June 2008)

\begin{abstract}
Laboratory experiments were carried out to evaluate the effect of three rhizobial strains (two of Rhizobium leguminosarum "127k80c and SU157" and one of Bradyrhizobium japonicum USDA110spc4) characterized previously as Plant Growth Promoting Rhizobacteria (PGPR) to affect the tested date palm micro propagation stages using tissue culture techniques. They were positive for the qualitative assessment of IAA and siderophore production. Different concentrations of each $(1,10,50$ and 100 $\mathrm{ml} / \mathrm{L}$ ) with around $6 \times 10^{9}$ viable cells were used in this evaluation to investigate the enhancement of callus formation, shoot and root number and length of this cultivar in comparison with the control growth regulator media containing synthesized phytohormones (2,4-D and 2ip). The survival percentage was $100 \%$ for all treatments. The results confirmed that the best callus formation value was achieved with the control medium $(2,4-D)$ followed by the addition of $\mathrm{MS}+10 \mathrm{ml} / \mathrm{L}$ of $127 \mathrm{k} 80 \mathrm{c}$ supernatant strain which recorded $77 \%$ and $66 \%$, respectively. Also, all the rhizobial supernatants stimulated the shoot formation and numbers of date palm c.v. zaghloul. On the other hand, there was no significant value on shoot length between the different treatments. Rhizobial supernatants of $B$. japonicum USDA110spc4 and $R$. leguminozarum $127 \mathrm{k} 8 \mathrm{oc}$ did stimulate strongly the root formation of this cultivar. Therefore, addition of rhizobial supernatants can be considered an effective tool, so that more studies and special attention should be paid to the possibility of using the tested rhizobial strains instead of synthesized phytohormones to reduce chemical substances and for its sheep costs, safe and ease handling.

Key words. Bradyrhizobium, date palm c.v. zaghloul, phytohormones, Rhizobium and tissue culture.
\end{abstract}

\section{INTRODUCTION}

Two general types of bacteria provide many benefits to plant. The first has symbiotic relationship with plant such as rhizobia and the other is free-living in the soil. Both of them have the ability to produce plant hormones and refer to be plant growth promoting rhizobacteria (PGPR). Ragab and Rashad, 2003 found that some strains of Rhizobium and Bradyrhizobium japonicum produce sidrophores and hydrocyanic acid (HCN) and indole acetic acid (IAA) under lab conditions which considered growth promoters substances (PGPR). Many scientists suggested that PGPR may have a positive effect on host growth due to production of plant growth 
substances which have a direct impact on host growth, accordingly, they could be used as an alternative product instead of chemical substances (Dileep Kumar et al., 2001, Ragab and Rashad, 2003 and Al Kahal et. al., 2003). Tissue culture technique is one of the most important techniques in agricultural research controlled by plant growth regulators (auxins, cytokinins, and gibbrellins). The cultures of MS basal medium supplemented with rhizobia supernatant strains without any addition of hormones seems to be containing considerable amount of cytokinin, Ganapath et al. (1994). Cytokinins are needed for multiplication, auxins for root formation and the balance between auxins and cytokinins is important for callus formation. These compounds are quite expensive and imported from various countries. Fortunately, they are produced and released by various symbiotic bacteria such as rhizobia. Therefore, the present study using tissue culture technique aims to determine the biological effect of different rhizobia strains selected as growth regulators producers using bioassay and chemical analyses on the different stages of date palm (Phoenix dactylifera L.) Zaghloul cultivation in vitro.

\section{MATERIALS AND METHODS}

This investigation was carried out in the Central Laboratory of Date Palm Research and Development and Soil Microbiology Dep., Soil, Water and Environment Res. Inst., Agric., Res. Center, Giza, Egypt. within 2006 months.

\section{Rhizobia strains and medium:}

Three rhizobia strains were used in this study as source of phytohormones one of them (strain-1) was Bradyrhizobium japonicum USDA110spc4 and the others (St-2 and St-3) were Rhizobium leguminosarum 127k80c and Su157. They were grown on YM broth medium (Vincent 1974) for 4 to 6 days to get the maximum viable cells numbers around $3-9 \times 10^{9} / \mathrm{ml}$. The rhizobia strains were characterized previously as Plant Growth Promotion Rhizobacteria (PGPR), they also were positive for the qualitative assessment of IAA, HCN and Sidrophore production (Ragab and Rashad, 2003).

\section{Plant material (shoot tip explants) and medium:}

This investigation was carried out in plant tissue culture laboratory using shoot tip explants of date palm (Phoenix dactylifera L.) zaghloul cultivar obtained from Badrasheen, Giza. The previous shoot tips were sterilized and cultured according to tissue culture techniques described by Bakry (1994). Consequently, all the following experiments were conducted using Murashige and Skoog (M.S) basal medium (1962) with either synthesized phytohormones or rhizobia supernatant (RS). Standard control medium for callus initiation stage consisted of MS basal medium supplemented with 100mg/L 2,4D (2,4Diclorophenoxy acetic acid) + 3mg/L 2ip (Isopentenyladenin), shooting stage consisted of MS basal medium supplemented with $1.0 \mathrm{mg} / \mathrm{l} 2 \mathrm{ip}$ and 
rooting stage consisted of MS basal medium supplemented with $0.1 \mathrm{mg} / \mathrm{L}$ NAA (Naphthalene acetic acid), were used El-Sharabasy (2000). While the rest of the treatments were depended on the MS basal medium + deferent concentrations of rhizobia supernatant strains. After preparation of the medium and adjusted PH to 5.7 with $1 \mathrm{~N} \mathrm{HCl}$ or $\mathrm{KOH}$. prior to agar addition The medium was poured into culture tubes (150x25mn) containing $20 \mathrm{ml}$ and closed with poly propylene closure. Culture tubes were autoclaved at $121^{\circ} \mathrm{C}$ for $20 \mathrm{~min}$. Two days later, $(1 \mathrm{ml}, 10 \mathrm{ml}, 50 \mathrm{ml}$, and 100 $\mathrm{ml}$ ) of rhizobia strains supernatant (St-1, St-2, and St-3) were added carefully and under sterilized conditions to the tusse culture prepared tubes which selected to be inoculated by rhizobia supernatant Three replicates of each strain or concentration was examined.

\section{Experiment treatments:}

Table (1) is showing the treatments of each of the tested three stages (callus formation, shooting and rooting). All experiment cultures were incubated at $25 \pm 2^{\circ} \mathrm{C}$. Light was provided by fluorescent tubes giving an intensity of 2000 lux for 16 hours / day. After 6 weeks the following parameters were determined: survival percentages for all the three stages, in addition to (callus formation percentage and average of callus value) for callus formation stage, (shoot number and shoot length) for both shooting and rooting stages, and finally (root percentage, number and length) for rooting stage.

Table 1. Experimental treatments of different stages

\begin{tabular}{|c|c|c|}
\hline \multicolumn{3}{|c|}{ Experiment treatments } \\
\hline Callus formation & Shoot formation & Root formation \\
\hline 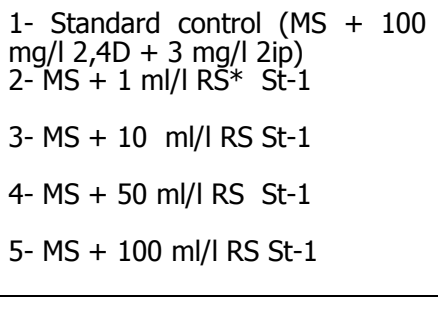 & $\begin{array}{l}\text { 1- Standard control (MS }+1.0 \\
\mathrm{mg} / \mathrm{l} \text { 2ip) } \\
\text { 2- MS }+1 \mathrm{ml} / \mathrm{l} \text { RS St-1 } \\
\text { 3- MS }+10 \mathrm{ml} / \mathrm{l} \text { RS St-1 } \\
\text { 4- } \mathrm{MS}+50 \mathrm{ml} / \mathrm{l} \text { RS St-1 } \\
\text { 5- } \mathrm{MS}+100 \mathrm{ml} / \mathrm{l} \mathrm{RS} \mathrm{St}-1\end{array}$ & $\begin{array}{l}\text { 1- Standard control (MS }+0.1 \\
\mathrm{mg} / \mathrm{l} \mathrm{NAA}) \\
\text { 2- MS }+1 \mathrm{ml} / \mathrm{l} \text { RS St-1 } \\
\text { 3- MS + } 10 \mathrm{ml} / \mathrm{l} \mathrm{RS} \mathrm{St}-1 \\
\text { 4- } \mathrm{MS}+50 \mathrm{ml} / \mathrm{l} \mathrm{RS} \mathrm{St}-1 \\
5-\mathrm{MS}+100 \mathrm{ml} / \mathrm{l} \mathrm{RS} \mathrm{St}-1\end{array}$ \\
\hline $\begin{array}{l}\text { 6- MS + } 1 \mathrm{ml} / \mathrm{l} \text { RS St-2 } \\
\text { 7- MS + } 10 \mathrm{ml} / \mathrm{l} \text { RS St-2 } \\
\text { 8- MS + } 50 \mathrm{ml} / \mathrm{l} \text { RS St-2 } \\
9-\mathrm{MS}+100 \mathrm{ml} / \mathrm{l} \text { RS St-2 }\end{array}$ & $\begin{array}{l}\text { 6- MS + } 1 \mathrm{ml} / \mathrm{l} \text { RS St-2 } \\
\text { 7- MS + } 10 \mathrm{ml} / \mathrm{l} \text { RS St-2 } \\
\text { 8- MS + } 50 \mathrm{ml} / \mathrm{l} \text { RS St-2 } \\
9-\mathrm{MS}+100 \mathrm{ml} / \mathrm{l} \mathrm{RS} \mathrm{St}-2\end{array}$ & $\begin{array}{l}\text { 6- MS + } 1 \mathrm{ml} / \mathrm{l} \text { RS St-2 } \\
\text { 7- MS }+10 \mathrm{ml} / \mathrm{l} \mathrm{RS} \mathrm{St}-2 \\
\text { 8- MS }+50 \mathrm{ml} / \mathrm{l} \mathrm{RS} \mathrm{St}-2 \\
9-\mathrm{MS}+100 \mathrm{ml} / \mathrm{l} \mathrm{RS} \mathrm{St}-2\end{array}$ \\
\hline $\begin{array}{l}10-\mathrm{MS}+1 \mathrm{ml} / \mathrm{l} \mathrm{RS} * \mathrm{St}-3 \\
11-\mathrm{MS}+10 \mathrm{ml} / \mathrm{l} \text { RS St-3 } \\
12-\mathrm{MS}+50 \mathrm{ml} / \mathrm{l} \text { RS St-3 } \\
13-\mathrm{MS}+100 \mathrm{ml} / \mathrm{l} \text { RS St-3 }\end{array}$ & $\begin{array}{l}10-\mathrm{MS}+1 \mathrm{ml} / \mathrm{l} \mathrm{RS} \mathrm{St}-3 \\
11-\mathrm{MS}+10 \mathrm{ml} / \mathrm{l} \text { RS St-3 } \\
12-\mathrm{MS}+50 \mathrm{ml} / \mathrm{l} \text { RS St-3 } \\
13-\mathrm{MS}+100 \mathrm{ml} / \mathrm{l} \mathrm{RS} \mathrm{St}-3\end{array}$ & $\begin{array}{l}10-\mathrm{MS}+1 \mathrm{ml} / \mathrm{l} \text { RS St-3 } \\
11-\mathrm{MS}+10 \mathrm{ml} / / \mathrm{RS} \mathrm{St}-3 \\
12-\mathrm{MS}+50 \mathrm{ml} / \mathrm{l} \text { RS St-3 } \\
13-\mathrm{MS}+100 \mathrm{ml} / \mathrm{l} \mathrm{RS} \mathrm{St}-3\end{array}$ \\
\hline
\end{tabular}

* "RS" means ( rhizobia supernatant).

The experiments were carried out using completely randomized blocks design and with three replicates. The results were analyzed using analysis of variance and 
the means were compared using L.S.D. at $5 \%$ level. All obtained data were subjected to analysis of variance completely randomized bloks according to snedecor and cochran, 1980.

\section{RESULTS}

\section{1- Effect of different concentrations of three rhizobia supernatant strains on callus formation of date palm (Phoenix dactylifra L.) Zaghloul cultivar.}

Table (2) showed that all different treatments had $100 \%$ survival. Data clearly showed that, the mean values of embryogenic callus ranged from 0 to 2.44 and the highest mass of embryogenic callus was recorded in response to the standard chemical control followed by the different treatments of rhizobia supernatant with the basal MS medium such as (S + $10 \mathrm{ml} / / \mathrm{RS}$ of St-2), (MS + $100 \mathrm{ml} / \mathrm{l} \mathrm{RS}$ of St-3) and (MS $+10 \mathrm{ml} / \mathrm{l}$ RS of St-1) which had embryogenic callus around 2.10, 1.33 and 1.10, respectively. In the mean while, no callus was formed with two RS additions, while the lowest mass was resulted from culturing in MS $+10 \mathrm{ml} / \mathrm{l} \mathrm{RS}$ of St-3 in the same time. Accordingly, the best results of callus formation percentage was achieved with the standard control treatment $77 \%$ against the other treatments of rhizobia supernatant strains which showed results from $33 \%$ to $66 \%$. Significant difference was noticed among the different treatments in callus formation stage.

Table 2. Effect of different concentrations of three rhizobia supernatant strains on callus formation of date palm (Phoenix dactylifra L.) Zaghloul cultivar.

\begin{tabular}{|c|c|c|c|c|c|c|c|c|c|c|}
\hline \multicolumn{2}{|c|}{ Treatments } & \multicolumn{3}{c|}{ Survival \% } & \multicolumn{3}{c|}{ Average of callus } & \multicolumn{3}{c|}{ Callus formation \% } \\
\hline No. & Conc. & St-1 & St-2 & St-3 & St-1 & St-2 & St-3 & St-1 & St-2 & St-3 \\
\hline 1 & Control & 100 & 100 & 100 & 2.44 & 2.44 & 2.44 & 77 & 77 & 77 \\
\hline 2 & $1 \mathrm{~m} 1 / 1$ & 100 & 100 & 100 & 0.66 & 1.06 & 0.00 & 33 & 44 & 0 \\
\hline 3 & $10 \mathrm{~m} 1 / 1$ & 100 & 100 & 100 & 1.10 & 2.10 & 0.22 & 44 & 66 & 22 \\
\hline 4 & $50 \mathrm{~m} 1 / 1$ & 100 & 100 & 100 & 0.44 & 0.99 & 0.99 & 33 & 33 & 44 \\
\hline 5 & $100 \mathrm{~m} 1 / 1$ & 100 & 100 & 100 & 0.00 & 0.77 & 1.33 & 0 & 33 & 55 \\
\hline L.S.D. ${ }^{0.05)}$ & & & \\
\end{tabular}

2- Effect of different concentrations of three rhizobia supernatant strains on shoot formation of date palm ( Phoenix dactylifera L.) Zaghloul cultivar.

Table (3) presented clearly that survival percentage was $100 \%$ for all concentrations in addition to standard control (growth regulators). Rhizobia 
supernatant (RS) strains were different in their effect on shoot number average. Whereas, the standard control showed 5.25 shoots/explant, the concentrations of 50 and $100 \mathrm{ml} / \mathrm{l}$ of RS St-1 appeared less numbers when announced 5.00 and 4.75 shoots/explant, respectively. On the other hand, St-2 and St-3 were promoted and introduced more efficiency than the standard control by announcing numbers of 5.50 and 6.50 shoots/explant for concentration of $10 \mathrm{ml} / \mathrm{l} \mathrm{RS}$ for both strains, respectively. So, the concentrations of $1 \mathrm{ml} / \mathrm{l} \mathrm{RS}$ of St-3 and $10 \mathrm{ml} / \mathrm{l} \mathrm{RS}$ of St-2 and St-3 gave same or better results than the standard control. In general, interaction between rhizobia supernatant and basal MS have great effect and significant differences among treatments of number of shoots formed, but the shoot length oppositely recorded non significant.

Table 3. Effect of different concentrations of three rhizobia supernatant strains on shooting formation of date palm (Poenix dactylifera L.) Zaghloul cultivar.

\begin{tabular}{|l|l|l|l|l|l|l|l|l|l|l|}
\hline \multicolumn{2}{|l|}{$\begin{array}{l}\text { Survival } \\
\%\end{array}$} & \multicolumn{3}{l|}{ Shoots number } & \multicolumn{3}{l|}{ Shoot length (Cm) } \\
\hline No. & $\begin{array}{l}\text { Conc. } \\
(\mathrm{mg} / \mathrm{l})\end{array}$ & St-1 & St-2 & St-3 & St-1 & St-2 & St-3 & St-1 & St-2 & St-3 \\
\hline 1 & Control & 100 & 100 & 100 & 5.25 & 5.25 & 5.25 & 1.75 & 1.75 & 1.75 \\
\hline 2 & $1 \mathrm{ml} / \mathrm{l}$ & 100 & 100 & 100 & 2.25 & 2.50 & 5.25 & 1.87 & 1.37 & 2.25 \\
\hline 3 & $10 \mathrm{ml} / \mathrm{l}$ & 100 & 100 & 100 & 2.50 & 5.50 & 6.50 & 1.63 & 1.62 & 1.75 \\
\hline 4 & $50 \mathrm{ml} / \mathrm{l}$ & 100 & 100 & 100 & 5.00 & 5.00 & 4.50 & 1.63 & 2.25 & 1.37 \\
\hline 5 & $100 \mathrm{ml} / \mathrm{l}$ & 100 & 100 & 100 & 4.75 & 3.50 & 3.75 & 2.00 & 1.87 & 2.15 \\
\hline
\end{tabular}

\section{3- Effect of different concentrations of three rhizobia supernatant strains} on rooting formation of date palm (Phoenix dactylifera L.) Zaghloul cultivar.

Survival percentage recorded $100 \%$ for all treatments ( Tables 4 and 5). Statistical analysis of variance showed almost no significance among strains when number of leaves, number of roots and root length were determined but there was among concentrations when roots numbers and root length were measured. Data represented in Table (4) revealed the effect of rhizobia supernatant on number of leaves when showed 2.77, 2.88 and 3.00 leaf/explant against 2.66 leaf/explant for standard control. Significant differences were resulted among strains with shoot length. The root formation data at Table (5) clarified that the rhizobia supernatant increased number of roots, root length and root percentage but not as much as the 
effect of medium control, so, the data illustrated results of 2.50 roots/explant, 3.00 $\mathrm{Cm}$ root length and the root average was $88.8 \%$ for the standard control which means the highest score of this stage followed by 2.16 roots/explant for $10 \mathrm{ml} / \mathrm{l}$ of RS St-2 and $50 \mathrm{ml} / \mathrm{l}$ of RS St-3, 2.50 and $2.33 \mathrm{~cm}$ of root length for the same strains and concentrations and lastly, root percentage of $88.8 \%$ for $10 \mathrm{ml} / \mathrm{l} \mathrm{RS}$ of St-1and $50 \mathrm{ml} / \mathrm{l}$ RS of St-2, respectively.

Table 4. Effect of different concentrations of three rhizobia supernatant strains on leaves and shooting formation of rooting stage of date palm (Poenix dactylifera L.) Zaghloul cultivar.

\begin{tabular}{|c|c|c|c|c|c|c|c|c|c|c|}
\hline \multicolumn{2}{|c|}{ Treatments } & \multicolumn{3}{|c|}{$\begin{array}{l}\text { Survival } \\
\%\end{array}$} & \multicolumn{3}{|c|}{ Leaves number } & \multicolumn{3}{|c|}{$\begin{array}{l}\text { Shoot length } \\
(\mathrm{Cm})\end{array}$} \\
\hline No. & Conc. & St-1 & St-2 & St-3 & St-1 & St-2 & St-3 & St-1 & St-2 & St-3 \\
\hline 1 & Control & 100 & 100 & 100 & 2.66 & 2.66 & 2.66 & 10.26 & 10.26 & 10.26 \\
\hline 2 & $1 \mathrm{ml} / \mathrm{l}$ & 100 & 100 & 100 & 2.88 & 2.66 & 2.55 & 9.53 & 14.66 & 10.26 \\
\hline 3 & $10 \mathrm{ml} / \mathrm{l}$ & 100 & 100 & 100 & 2.66 & 2.55 & 2.77 & 10.60 & 12.60 & 10.43 \\
\hline 4 & $50 \mathrm{ml} / \mathrm{l}$ & 100 & 100 & 100 & 2.77 & 2.44 & 2.88 & 9.43 & 12.76 & 9.36 \\
\hline 5 & $100 \mathrm{ml} / \mathrm{l}$ & 100 & 100 & 100 & 2.88 & 3.00 & 2.55 & 9.43 & 14.60 & 9.66 \\
\hline \multicolumn{5}{|c|}{ L. S. $\mathbf{D}^{(0.05)}$} & \multicolumn{3}{|c|}{$\begin{aligned} A & =N . S \\
B & =N . S \\
A \times B & =N . S\end{aligned}$} & \multicolumn{3}{|c|}{$\begin{array}{l}A=1.194 \\
B=N . S \\
A \times B=N . S\end{array}$} \\
\hline
\end{tabular}

Table 5. Effect of different concentrations of three rhizobia supernatant strains on root formation of date palm (Phoenix dactylifera L.) Zaghloul cultivar.

\begin{tabular}{|c|c|c|c|c|c|c|c|c|c|c|c|c|c|}
\hline \multicolumn{2}{|c|}{ Treatments } & \multicolumn{3}{|c|}{$\begin{array}{l}\text { Survival } \\
\%\end{array}$} & \multicolumn{3}{|c|}{ Roots number } & \multicolumn{3}{|c|}{ Root length $(\mathrm{Cm})$} & \multicolumn{3}{|c|}{$\begin{array}{l}\text { Rooting } \\
\%\end{array}$} \\
\hline No. & Conc. & St-1 & St-2 & St-3 & St-1 & St-2 & St-3 & St-1 & St-2 & St-3 & $\begin{array}{l}\text { St- } \\
1\end{array}$ & St-2 & St-3 \\
\hline 1 & Control & 100 & 100 & 100 & 2.50 & 2.50 & 2.50 & 3.00 & 3.00 & 3.00 & 88.8 & 88.8 & 88.8 \\
\hline 2 & $1 \mathrm{ml} / \mathrm{l}$ & 100 & 100 & 100 & 1.33 & 1.16 & 0.00 & 1.50 & 1.33 & 0.00 & 55.5 & 33.3 & 0.00 \\
\hline 3 & $10 \mathrm{ml} / \mathrm{l}$ & 100 & 100 & 100 & 2.00 & 2.16 & 1.16 & 2.16 & 2.50 & 1.50 & 88.8 & 66.6 & 33.3 \\
\hline 4 & $50 \mathrm{ml} / \mathrm{l}$ & 100 & 100 & 100 & 1.16 & 1.50 & 2.16 & 1.50 & 2.00 & 2.33 & 55.5 & 88.8 & 77.7 \\
\hline 5 & $100 \mathrm{ml} / \mathrm{l}$ & 100 & 100 & 100 & 0.88 & 0.50 & 1.16 & 1.00 & 0.83 & 1.66 & 33.3 & 33.3 & 66.6 \\
\hline \multicolumn{5}{|c|}{ L. S. $\mathbf{D}^{(0.05)}$} & \multicolumn{3}{|c|}{$\begin{array}{ll}\mathrm{A} & =\mathrm{N} . \mathrm{S} \\
\mathrm{B} & =0.741 \\
\mathrm{~A} \times \mathrm{B} & =\text { N. S }\end{array}$} & \multicolumn{3}{|c|}{$\begin{array}{ll}A & =N . S \\
B & =0.82 \\
A \times B & =N . S\end{array}$} & & & \\
\hline
\end{tabular}

\section{DISCUSSION}

Survival of all stages was $100 \%$ which means that there is no harmful was happened or toxic excretes was produced with rhizobia supernatant strains usage as PGPR. In this respect, Emara (1995) mentioned that in tissue culture of higher plant regulators, especially auxins and cytokinins, are very significant. It can be said that in vitro culture is often impossible without regulators whether an auxin and/or a 
cytokinin had to be added to create a balance between them to a nutrient medium cell extension and/or cell division which is completely dependent on the type of explant and plant species. Auxins and cytokinins will produce varied effects depending upon the type of compound and the concentration. Mater (1987) noted that, embryos were regenerated by sub culturing on a medium containing NAA at $0.1 \mathrm{mg} / \mathrm{l}$ and charcoal while adventitious roots and shoots were induced by transfer to the same medium devoid of charcoal. The results in this study clearly show that, there are many components in rhizobia supernatant but it was strongly stimulated the proliferation of secondary embryos, shoots and callus development. It also was in harmony with Zaid and Tisserat (1983) who reported that, the best consistent shoot regeneration was occurred on medium containing NAA, or with Khan et al., (1983) who observed that, NAA with cytokinin induced callus growth and root initiation. Also, it could be observed that, the different stages of growth (callus, shooting and rooting) could be affected significantly the changing of strains and concentrations.

The cultures of MS basal medium supplemented with rhizobia supernatant strains stimulated multiple shoot formation which seams to be containing considerable amount of cytokinin, auxins and other hormones, this was in agreement with Ganapath et al. (1994). Additionally, many other scientists suggested that PGPR may have a positive effect on host growth due to production of plant growth substances which have a direct impact on host growth, evidently, with the concept that the in vitro multiplication rate is a function of cytokinin concentration, El-khawas et al. (1995) and Beylers et al (1997). An other considerable idea of Tisserat (1982), Mater (1986), Zaid (1987), Al-Ghamdi (1993) and El-Sharabasy (2000) who reported the necessity to add high level of auxin as hormonal stimulator for callus induction and formation.

The successes results of the combination between tissue culture techniques and rhizobia supernatant inoculation was in accordance with Kapulnik et al. (1985) and Whallon et al. (1985) and Rashad and Ragab (2003) who indicated that if PGPR colonization was located mainly on the cell elongation area and on the bases of the root hairs, then, the growth accordingly can be increased. Lastly, several investigators with supportive evidences were previously reported that the significant favorable effects of (PGPR) on the growth and productivity of the treated plants may be explained on 1) the basis of the beneficial of bacteria on the nutrient availability, 2) vital enzymes, 3) hormonal stimulating effects on plant growth or 4) increasing of photosynthetic activity. 


\section{REFERENCES}

1. Al-Ghamdi. 1993. True-to- tube date palm (Phoenix dactylifera L.) produce through tissue culture technique. J. Produce of Planters in Vitro. The third symposium on date palm in Saudi Arabia, pp. 57-63.

2. Beyler, M. P. Michaux: C. Kell and D. Hass. 1997. Effect of enhanced production of indol-3-acetic acid by the biological control agent Psudomonas flurescens CHAO on plant growth. In: Ogoshi A, Kobayashi K, Homma Y, Kadoma F, Kondo N, Akino S(eds) Proceedings of the Fourth International Workshop on Plant Growthpromoting Rhizobacteria, Sapporo, Japan, pp 310-312.

3. Dileep Kumar, B. S., I. Berygrenn and A. M. Martensson. 2001. Potential for improving Pea production by co-inoculation with Fluorescent pseudomonas and Rhizobium. Plant and Soil, 22(a) , 25-34.

4. Emara, H. A. 1995. The use of tissue culture techniques to produce some ornamental plants. Ph. D. Thesis. Zagazig Univ. Egypt.

5. El-Sharabasy, S. 2000. Studies of the production of some secondary metabolites from Date Palm (Phoenix dactylifera L.) by using tissue culture technique.

6. Ganapath, T. R., P. Suprasanma, V. A. Bapat and P. S. Rao. 1994. Stimulatory effect of cyanobacteria extract on banana shoots tip cultures. Tropical Agricul., 71 (4) 299-302.

7. Khan, M. A. , M. S. Khalil, M. S. Al-Kahtani. 1983. In vitro culture of different tissue of date palm (Phoenix dactylifera L.) of shoot. Proceedings of the first symposium on the date palm in Saudi Arabia. 152-157.

8. Kapulnik, Y., Y. Oko and Y. Hens. 1985. Changes in root morphology of wheat caused by Azospirillum inoculation. Can. J. Microb., 31 :881-887.

9. Mater, A. A. 1986. In vitro propagation of Phoenix dactylifera L. Date Palm J. 4: (2) $137-152$.

10. Mater, A. A. 1987. Production and cryogenic freezing of date palm germplasm and regeneration of plantlets from frozen material. Iraqi J. Agric. Sci., ZANCO. 5: 35-49.

11. Murashige, T. and F. Skoog. 1962. A revised medium for rapid growth and bioassays with tobacco tissues. Physio. Plant, 15: 473-497.

12. Sendcor, G. W. and W.G. Cochran. 1980. "Statistical Methods". Oxford and Y.B.H. Publishing Co., $6^{\text {th }}$ Edition. 
13. Ragab, A. A. and A. H. Rashad. 2003. Enhancement of nutrients uptake and metabolism efficiency of sorghum (Sorghum bicolor L.) plants by biofertilizer under water stress. Zagazig, J. Agric. Res., 30 No(1): 147-166.

14. Rashad, M. H. and A. A. Ragab. 2003. Use of biofertilizers as effective tool for growth and yield in sorghum (Sorghum bicolor L.) plants under different soil moisture. Zagazig J. Agric. Res. , Vol. 30, No. (1) 2003,pp 167-185.

15. Tisserat, B. 1982. Factors involved in the production of plantlets from date palm callus cultures. Euphytica, 31: (1) 201-214.

16. Vincent, J. M. 1974. Root-nodule symbiosis with Rhizobium. In A. Quspel (ed.). The Biology of Nitrogen Fixation, North Holand Publishing company, Amesterdam. p: $265-341$.

17. Zaid, A. and B. Tisserat. 1983. In vitro shoot tip differentiation in Phoenix dactylifera L. Date Palm J. 2: (2) 163-182. 
أثز الفيتوهرمونات المنتجه ببعض سلالات الريزوييا علي إكثار نخيل البلح Phoenix dactylifera L

شريف الثرياصي' ، ضياء سويلمّ ، عاطف عبد العزيز رجب

ا ـ معدل المركزي لبحوث تطوبير النخيل. مركز البحوث الزراعيه. الجيزه

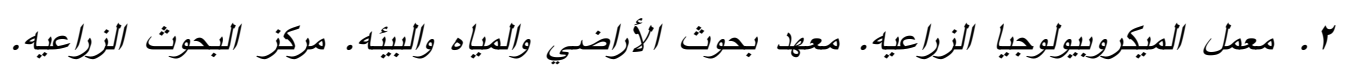
الجيزه

أجريت هذه التجارب لتقييم أثز بعض سلالات الريزوبيا ( Rhizobium leguminosarum "127k80c ) والتي نم تصنيفها مسبقا بأنها ( and SU157" - Bradyrhizobium japonicum USDA110spc4) Phoenix (PGPR) بكتريا مشجعه لنمو النبات بالمنطقه الجذريه (dactylifera L

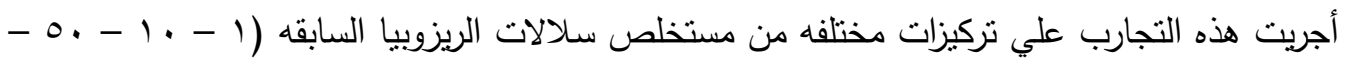

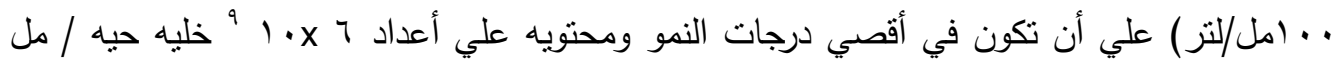

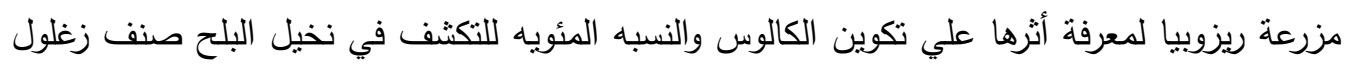
المختبر وتكوين الأفرع والجذور وإستطالتها وذلك بمقارنتها بالبيئه الكيماويه المنلي لكل مرحله من هذها

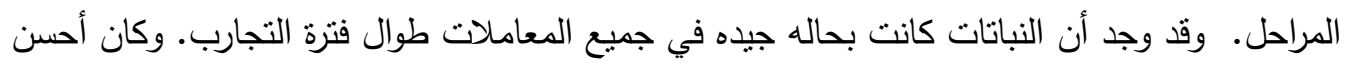

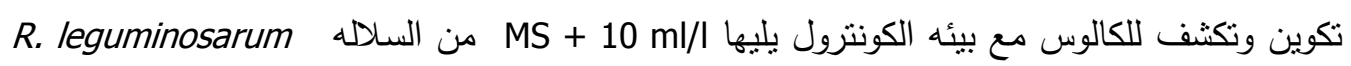
127K80c

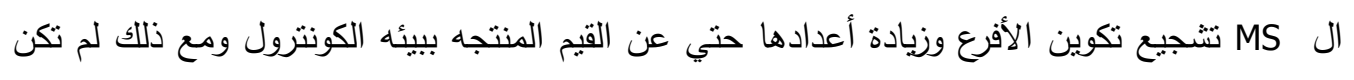

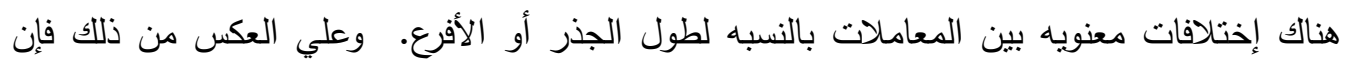

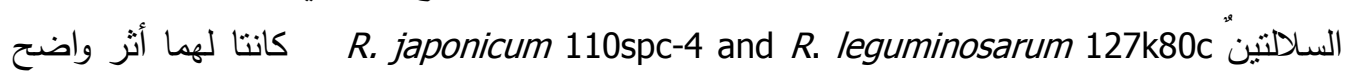
علي زيادة تكوين الجذور في هذا الصنف من نخيل البلح. 